\title{
STENOSING TENOSYNOVITIS
}

\author{
BY \\ G. PALMBORG \\ From the Department of Rheumatic Diseases, Södersjukhuset, Stockholm, Sweden
}

(RECEIVED FOR PUBLICATION APRIL 15, 1952)

Quervain's disease (stenosing tenosynovitis at the radio-styloid process) is a disability of the wrist due to a stricture of the ligamentous synovium-lined sheath over the prominence of the radio-styloid process, i.e. the sheath through which run the tendons of the extensor pollicis brevis and of the abductor pollicis longus. The tendon sheath and those parts of the ligamentum carpi dorsale forming this tunnel thicken and thereby constrict the tendons. These changes make movements of the thumb and of the hand painful, often severely so. Moreover, aching may radiate persistently down towards the thumb and up the arm, sometimes as far as the shoulder.

The disease was named after the Swiss surgeon F. de Quervain, who described the condition in 1895. Since then workers in this field have often called attention to the disease, especially as it seems to be very easily forgotten in investigating painful conditions of the wrist.

As is well known, six tunnels extend beneath the ligamentum dorsale, providing sheaths for the extensor tendons of the hands. The tendon of the extensor pollicis brevis and that of the abductor pollicis longus pass through the first sheath, as described above. The tendon of the extensor carpi radialis brevis and that of the extensor carpi radialis longus pass through the second sheath, the tendon of the extensor pollicis longus through the third, and those of the extensor indicis and of the extensor digitorum communis through the fourth, which is the widest. The tendon of the extensor digiti quinti proprius passes through the fifth sheath and that of the extensor carpi ulnaris through the sixth.

\section{- Stenosis of Sheaths other than the First}

Stenosis of the first sheath-Quervain's diseaseis fairly common, but, judging by the scanty reports available, stenosis of the other five sheaths, though by no means unknown, is quite rare. This may be explained by the different anatomical relationship of the first sheath which renders it more exposed to mechanical strain and the risk of injury.
Perusal of the literature revealed one case of stenosing tenosynovitis of the second sheath (extensor carpi radialis longus et brevis) described by Jagerink (1928), one case involving both the second and the third sheaths by Muller (1950), and three cases involving the third sheath (extensor pollicis longus) by Winterstein (1928), Pohl (1936), and Liavaag (1945). Winterstein (1930) also reported one case of the condition in the fourth sheath (extensor digitorum communis) and one in the fifth (extensor digiti quinti proprius). In all of these cases complete relief had been obtained by operation. Despite a fairly thorough search of the literature no certain case of the condition in the sixth sheath (extensor carpi ulnaris) could be traced.

Surgically treated cases of analogous stenosis elsewhere have been described. Winterstein (1930) reported a case of stenosis of the sheath of the flexor carpi radialis, the anatomy of which resembles that of the extensor tendons. Stenosis of the peroneus sheath under the retinaculum peronei inferius was described by Hackenbroch (1927, two cases) and by Woltereck (1927, one case). Jagerink (1928) reported a case of the condition in the sheath of the tendon of the tibialis anterior. A remarkable case of stenosis of a tendon sheath was described by Shepherd (1946). Here the condition was seen in the sheath of the extensor pollicis brevis, which in this case ran through a sheath by itself, and the condition was due to a fibro-cartilaginous formation that had developed within the sheath.

Aetiology.-As to the aetiology of stenosing tenosynovitis, all seem to agree that it is chiefly due to mechanical factors. Wherever tendon sheaths are reinforced by ligamentous bands the sheaths may become too narrow for the tendons or the tendons may become too thick for the sheathsFinkelstein (1930) and Wiberg (1941) called attention to trauma as an aetiological factor. As to the pathological anatomy, suffice it here to say that signs of inflammation of the tendons or of the tendon 
sheaths are rare and that, when seen, they are scanty and chronic.

Symptoms.-The symptoms of the conditions in other sheaths on the dorsal surface of the wrist are, as may be expected, similar to those of Quervain's disease. The use of the hand causes pain in the wrist and in one or more of the fingers, and aching which radiates down the hand or up the arm. The area over the affected tendon sheath is swollen and tender, but digital pressure against the rest of the wrist will not produce pain. In the cases reported in the literature, the pain was described as severe and sometimes intense enough to incapacitate the patient for a long period.

\section{Stenosis of the Sixth Sheath}

As mentioned above, a search of the literature failed to reveal any instance of certain stenosis of the sixth sheath under the ligamentum carpi dorsale. Winterstein (1928) described two cases, one of which was, however, afterwards reported by him as a diagnostic error and found to be stenosis of the fifth sheath (extensor digiti quinti), the other case was not typical and was not submitted to operation.

As no reports of certain cases of stenosis of the sixth sheath are on record, the following case was considered worth reporting.

Case Report.-A 22-year-old female sought advice for pain in her right hand: when she moved it pain radiated from the wrist down the hand and up the arm. At first the pain was mild and occurred only after strenuous work, but the symptoms gradually became worse, and very light work - even writing - began to cause severe pain followed by increasingly prolonged aching that made the use of the hand almost impossible.

The pain was most severe on the ulnar aspect of the wrist and the lower arm, whence it radiated up towards the elbow. During the previous 6 months she had noticed an occasional swelling over the back of the wrist. Immobilization gave relief, but the pain returned as soon as she began to use the hand. She had received thermotherapy and massage, which only worsened the condition.

On May 19, 1948, the patient was referred to the department of physical therapy at Södersjukhuset for investigation. Examination there revealed a hard swelling, $1 \mathrm{~cm}$. long, which was felt immediately over the processus styloideus ulnae and which seemed to change in shape and size on flexion and extension of the hand. These movements caused considerable pain and the area over the swelling was tender to palpation, but digital pressure against the rest of the wrist caused no pain. Radiographs of the wrist and the lower part of the arm showed no signs of a pathological condition. The patient seemed to be otherwise healthy, showing no signs of disease, at any rate not of rheumatic disease.
As the symptoms suggested Quervain's disease, the patient was referred to the department of surgery for presumed tendovaginitis of the sixth sheath. At operation (carried out by Dr. T. Ekblom) the ligamentum carpi dorsale over the sixth compartment was found to be considerably thickened. Division of the ligamentum showed that the tendon was compressed and constricted along its passage through the tendon sheath. Proximal to the stricture the tendon was swollen and spool-like, with a rough surface. The sheath contained no exudate and showed no signs of inflammation. Immediately. after division of the ligamentum, the patient reported that movements of the hand had become much more free. Biopsy specimens were removed from the tendon and sheath, and the skin was sutured over the sheath, which was left open. Histological examination of the tissue specimens showed only connective tissue proliferation and regressive changes without signs of inflammation. The post-operative course was smooth, and when the patient was seen again in August, 1948, she reported complete relief.

\section{Conclusions}

With the exception of Quervain's disease, stenosing tendovaginitis of the wrist seems to be rare, at least as far as cases giving symptoms severe enough to indicate operation are concerned. It does not seem unreasonable to suppose that less advanced cases may be relieved by immobilization and other conservative measures and may thereby remain undiagnosed. If it be borne in mind that prolonged, diffuse pain in the hand or wrist may often be ascribed to stenosing tendovaginitis, it is possible that this condition, which may suitably be called tendovaginitis stenosans carpi, is not in fact so rare as hitherto supposed.

\section{Summary}

Quervain's disease is briefly described. It is pointed out that similar stenosis can occur, not only in other tendon sheaths of the back of the hand, but also elsewhere. The literature is summarized, and it is stressed that no certain case of the condition has hitherto been seen in the sixth tendon sheath of the wrist through which passes the extensor carpi ulnaris.

A case is reported which was diagnosed by the author and submitted to operation with complete subsequent relief. The patient presented symptoms characteristic of Quervain's disease, but localized in the ulnar part of the wrist.

Stenosis of tendon sheaths, other than the most radial sheath on the dorsal side of the wrist, is probably not so rare as hitherto supposed. It might be diagnosed more frequently if the possibility of its presence were remembered.

Such a condition might be called tendovaginitis stenosans carpi. 
BIBLIOGRAPHY

Finkelstein, H. (1930). J. Bone Jt Surg., 12, 509.

Hackenbroch, M. L. (1927). Münch. med. Wschr., 74, 932.

Jagerink, T. A. (1928). Nederl. T. Geneesk., 72, 3228.

Jagerink, T. A. (1928). Nederl. T. Genees

Liavaag, K. (1945). Nord. Med., 28, 2617.

Muller, H. (1950). Arch. chir. neerl., $2,188$.

Palmborg, G. (1948). Svenska LäkT., 45, 999.

(1949). Ibid., 46, 2768.

Pohl, H. (1936). Med. Klin., 32, 1596.

Quervain, F. de (1895). KorrespBl. schweiz. Ärz., 25, 389.

Quervain, F. (1912). Münch. med. Wschr., 59, 5. (1931). "Spezielle chirurgische Diagnostik," 9th ed., p. 691.
Vogel, Leipzig.

Shepherd, J. A. (1946). Brit. J. Surg., 34, 213.

Wiberg, G. (1941). Nord. Med., 10, 1929

Winterstein, O. (1928). Schweiz. med. Wschr., 58, 746

- (1930). Zbl. Chir., 57, 1347.

Woltereck, K. (1927). "Ueber die stenosierende Tendovaginitis (de Quervain) und ihre atypischen Lokalisationen." Inaugural dissertation. Cologne.

\section{Ténosynovite sténosante}

RÉSUMÉ

On décrit brèvement la maladie de Quervain. On montre que des sténoses similaires peuvent survenir non seulement dans d'autres gaines tendineuses du dos de la main, mais aussi ailleurs. On présente un résumé de la littérature sur ce sujet et on souligne qu'aucun cas certain de cette affection n'a été observé dans la sixième gaine tendineuse du poignet, donnant passage à l'extenseur interne du carpe.

L'auteur a fait le diagnostic d'un cas rapporté ici; l'opération fut suivie d'un soulagement complet. Le malade avait présenté des symptômes caractéristiques de la maladie de Quervain, mais leur siège était du coté interne du poignet.

La sténose des gaines tendineuses autres que la gaine la plus externe du dos du poignet n'est probablement pas aussi rare qu'on serait porté à le croire. On en ferait le diagnostic plus souvent si on y pensait.

On pourrait donner à cette affection le nom de ténovaginite sténosante du carpe.

\section{Tenosinovitis estenosante}

Sumario

Se describe sucintamente la enfermedad de Quervain. Se señala que estenosis similares pueden ocurrir no sólo en otras vainas tendinosas del dorso de la mano, sino tambien en otras partes. Después de resumir la literatura sobre este sujeto, se subraya el hecho de que no se haya observado caso cierto de esta afección en la sexta vaina tendinosa de la muñeca, atravesada por el extensor carpi ulnaris.

El autor relata un caso diagnosticado por él, en que una operación alivió al enfermo completamente. Este había presentado los síntomas característicos de la enfermedad de Quervain, localizados, sin embargo, en la parte cubital de la muñeca.

La estenosis de las vainas tendinosas de la parte dorsal de la muñeca no es probablemente tan rara como parece. Se la diagnosticaría más a menudo si se pensara en su posibilidad.

Se podría dar a esta afección el nombre de tendovaginitis stenosans carpi. 